\title{
Activation of $\beta$-adrenergic receptor promotes cellular proliferation in human glioblastoma
}

\author{
JING-JING HE ${ }^{1 *}$, WEN-HUA ZHANG ${ }^{2 *}$, SHI-LING LIU ${ }^{1}$, YI-FANG CHEN ${ }^{1}$, \\ CHEN-XI LIAO $^{1}$, QIAN-QING SHEN ${ }^{1}$ and PING HU ${ }^{1}$ \\ ${ }^{1}$ Institute of Translational Medicine, Nanchang University, Nanchang, Jiangxi 330001; \\ ${ }^{2}$ Institute of Life Science, Nanchang University, Nanchang, Jiangxi 330031, P.R. China
}

Received October 27, 2016; Accepted April 13, 2017

DOI: $10.3892 / \mathrm{ol} .2017 .6653$

\begin{abstract}
Glioblastoma multiforme is the most common and aggressive form of primary malignant brain tumor. Previous evidence demonstrates that $\beta$-adrenergic receptors ( $\beta$-ARs) are closely associated with the occurrence and development of brain tumors. However, the functional role of $\beta$-ARs in human glioblastoma and the underlying mechanisms are not fully understood. In the present study, by using the MTT assay, western blotting, and the reverse transcription polymerase chain reaction, it was revealed that isoproterenol (ISO), an agonist of $\beta$-ARs, promoted the proliferation of U251 cells but not U87-MG cells, and that this effect was blocked by the $\beta$-ARs antagonist propranolol. It was also demonstrated that ISO transiently induced extracellular signal-related kinase 1/2 (ERK1/2) phosphorylation, and that blocking the mitogen-activated protein kinase pathway by U0126 inhibited ERK1/2 phosphorylation and suppressed U251 cell proliferation. In addition, $\beta$-ARs activation increased the expression of matrix metalloproteinase (MMP) family members $M M P-2$ and $M M P-9$ mRNA through ERK1/2 activation. In conclusion, these data suggest that $\beta$-ARs induce ERK1/2 phosphorylation, which may in turn increase MMPs expression to promote U251 cell proliferation. These results provide additional insight into the specific roles of $\beta$-ARs in glioblastoma.
\end{abstract}

\section{Introduction}

Glioblastoma multiforme (GBM), or grade IV astrocytoma as classified by the World Health Organization (1), is the most common and malignant primary brain tumor in humans, with

Correspondence to: $\mathrm{Dr} \mathrm{Ping} \mathrm{Hu}$, Institute of Translational Medicine, Nanchang University, 1299 Xuefu Avenue, Xinjian, Nanchang, Jiangxi 330001, P.R. China

E-mail: canyhp@ncu.edu.cn

*Contributed equally

Key words: glioblastoma, $\beta$-adrenergic receptor, isoproterenol, proliferation, mitogen-activated protein kinase an incidence rate of 3.19 cases per 100,000 person/year in the United States 2005-2009 (1). The important characteristics of GBM are the high cellular proliferation rate, genetic instability, diffuse infiltration and high angiogenesis, conferring high levels of aggression and drug resistance in GBM (2). In spite of previous significant improvements in treatment, including surgery, radiotherapy and chemotherapy, the overall median survival rate remains only 12-16 months at present (3). This poor prognosis suggests that therapeutic resistance is a significant problem of GBM. Thus, it is urgent to identify novel candidate factors involved in glioma proliferation and angiogenesis that may assist to develop effective targeted therapies for GBM.

A growing number of studies have demonstrated that exposure to stress may promote tumor progression in many types of cancers (4-6) and the adrenergic system has been widely recognized to serve a significant role in stress signaling (7). Exposure to stressful events induces the activation of the hypothalamic-pituitary-adrenal (HPA) axis, which in turn results in the release of glucocorticoids and catecholamines, including norepinephrine (NE) and epinephrine (E), from the adrenal gland and from the brain and sympathetic nerve terminals (8). Concurrently, the secretion of dopamine, which assists to control the reward and pleasure centers of the brain, is reduced. This alteration in homeostasis leads to a microenvironment that is beneficial to tumor growth and progression in experimental models of disease (5). The functions of NE and $\mathrm{E}$ are primarily mediated by the activation of adrenergic receptors (ARs) including $\alpha$-ARs and $\beta$-ARs (9). There are 3 subtypes of $\beta$-ARs, specifically $\beta_{1}-A R, \beta_{2}$-AR and $\beta_{3}$-AR, which have been identified to date (10). $\beta_{1}$-ARs and $\beta_{2}$-ARs are widely expressed in the majority of mammalian cell types, while $\beta_{3}$-ARs are almost exclusively expressed in adipocytes that have seldom been studied (11).

$\beta$-ARs are members of the superfamily of $G$ protein-coupled receptors (GPCR), which activate the Gas protein to initiate multiple signaling cascades and therefore lead to numerous pathological conditions such as cardiac, psychiatric, immunological and endocrine disorders (12). In previous decades, numerous studies have demonstrated that $\beta$-ARs may also regulate different processes of cancer initiation and progression, through activating the classical cyclic adenosine monophosphate (cAMP)/protein kinase A (PKA) pathway and 
mitogen-activated protein kinases (MAPK) pathway $(13,14)$. For example, in pancreatic ductal adenocarcinomas cells, it has been suggested that $\beta$-AR agonists promote cell growth by activating signaling via adenylyl cyclase (AC) and its downstream effectors cAMP, PKA and nuclear transcription factor cAMP-responsive element-binding protein (15). In addition, the extracellular signal-related kinase 1/2 (ERK1/2) signaling pathway, activated by transactivating epidermal growth factor receptor (EGFR), is also associated with this process $(16,17)$. Previously, the potential involvement of $\beta$-ARs in the modulation of astrocytoma cancer cell proliferation has been suggested (18). However, the detailed underlying mechanisms by which these events occur remain unknown, but are becoming characterized.

The present study was designed to investigate the function and mechanism of $\beta$-ARs in human glioblastoma U251 cells. The results demonstrated that the $\beta_{1}$-AR and $\beta_{2}$-AR subtypes were expressed in U251 cells but not U87-MG cells. In addition, the activation of the $\beta$-ARs by isoproterenol (ISO) significantly enhanced the rate of cell proliferation in U251 cells via activation of the ERK1/2 pathway and matrix metalloproteinase (MMP)-2 and MMP-9 mRNA expression. These results may provide additional insight into the specific roles of $\beta$-ARs in glioblastoma.

\section{Materials and methods}

Antibodies and reagents. Primary antibodies including phospho-ERK1/2 (Thr202/Tyr204) (cat no. 9101; 1:2,000), ERK1/2 (cat no. 9102; 1:2,000) and $\beta$-actin (cat no. 4970; $1: 4,000)$, the secondary antibody horseradish peroxidase (HRP)-linked goat anti-rabbit IgG antibody (cat no. 7074; 1:20,000) and U0126 (a specific ERK1/2 inhibitor) were purchased from Cell Signaling Technology, Inc. (Danvers, MA, USA). ISO and propranolol (PRO) were purchased from Tocris Bioscience (Bristol, UK). The culture medium and other solutions used for cell culture were purchased from Invitrogen, Thermo Fisher Scientific, Inc. (Waltham, MA, USA). MTT was purchased from Carl Roth GmbH \& Co., KG (Karlsruhe, Germany).

Cell culture. Human glioblastoma cell lines U87-MG and U251 were grown in Dulbecco's modified Eagle's medium (DMEM) containing $4.5 \mathrm{~g} / 1$ glucose supplemented with $10 \%$ fetal bovine serum (FBS; Gibco; Thermo Fisher Scientific, Inc.), $2 \mathrm{mM}$ glutamine, $50 \mu \mathrm{g} / \mathrm{ml}$ streptomycin and $50 \mathrm{IU} / \mathrm{ml}$ penicillin. Cultures were maintained at $37^{\circ} \mathrm{C}$ in a humidified atmosphere containing $5 \% \mathrm{CO}_{2}$.

Reverse transcription polymerase chain reaction (RT-PCR). The total cellular RNA from the U251 and U87-MG cells was extracted using TRIzol reagent according to the manufacturer's protocol (Thermo Fisher Scientific, Inc.). The RNA concentration was measured using NanoDrop 2000 (Thermo Fisher Scientific, Inc.). Then the RNA was reverse transcribed into cDNA using SuperScript III reverse transcriptase according to the manufacturer's protocol (Thermo Fisher Scientific, Inc.). PCR amplification was performed using $5 \mu \mathrm{l}$ cDNA, $12.5 \mu \mathrm{l}$ 2X Taq PCR Master Mix (Promega Corporation, Madison, WI, USA), $0.5 \mu \mathrm{l} 10 \mu \mathrm{M}$ forward primer, $0.5 \mu \mathrm{l} 10 \mu \mathrm{M}$

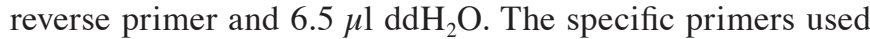
are summarized in Table I. The thermocycling protocol was as follows: Amplification step, $94^{\circ} \mathrm{C}$ for $5 \mathrm{~min}$; 30 cycles of denaturation for $1 \mathrm{~min}$ at $95^{\circ} \mathrm{C} ; 1 \mathrm{~min}$ of annealing at $55^{\circ} \mathrm{C}$; elongation at $72^{\circ} \mathrm{C}$ for $1 \mathrm{~min}$; and extension at $72^{\circ} \mathrm{C}$ for $1 \mathrm{~min}$. The PCR products were electrophoresed on a $1.5 \%$ agarose gel and the bands in the gels that were stained with ethidium bromide were visualized under ultraviolet light transilluminators (ChemiDoc XRS+ system; Bio-Rad Laboratories, Inc., Hercules, CA, USA). The gene $\beta$-actin was used as a control.

RT-quantitative PCR ( $q P C R)$. The total RNA and cDNA were obtained as aforementioned. The PCR primers used for the analysis are summarized in Table I. The $20 \mu \mathrm{l}$ PCR system was composed of $2 \mu \mathrm{l}$ cDNA, $10 \mu \mathrm{l} \mathrm{SYBR}{ }^{\circledR}$ Premix Ex Taq II, $0.4 \mu 1$ ROX Reference Dye II (Takara Bio, Inc., Otsu, Japan), $0.8 \mu \mathrm{l} 10 \mu \mathrm{M}$ forward primer, $0.8 \mu \mathrm{l} 10 \mu \mathrm{M}$ reverse primer and $6 \mu \mathrm{l}$ double-distilled $\mathrm{H}_{2} \mathrm{O}$. The RT-qPCR amplification was performed using the ViiA7 system (Applied Biosystems; Thermo Fisher Scientific, Inc.) under the following thermocycler conditions: $95^{\circ} \mathrm{C}$ for $30 \mathrm{sec}$; 40 cycles of denaturation for $5 \mathrm{sec}$ at $95^{\circ} \mathrm{C} ; 34 \mathrm{sec}$ of annealing at $60^{\circ} \mathrm{C}$; elongation at $95^{\circ} \mathrm{C}$ for $15 \mathrm{sec}$; and extension at $60^{\circ} \mathrm{C}$ for $1 \mathrm{~min}$. The quantification method for qPCR data was the $2^{-\Delta \Delta C q}$ method (19). At least three independent experiments were conducted and samples were assessed in triplicate for each experiment. The same PCR system as above was used without template cDNA was used as a negative control.

Western blot analysis. Cells were cultured in serum-free DMEM overnight at $37^{\circ} \mathrm{C}$ prior to drug treatment. To determine the time course effect of ISO on ERK1/2 activation, cells were treated with ISO $(10 \mu \mathrm{M})$ for $1,2,5,10,20$ and $30 \mathrm{~min}$ at $37^{\circ} \mathrm{C}$. To determine the effects of propranolol (PRO) and U0126 on ISO-mediated ERK1/2 activation, cells were pretreated with PRO $(10 \mu \mathrm{M})$ or U0126 $(20 \mu \mathrm{M})$ for $30 \mathrm{~min}$ and then with ISO $(10 \mu \mathrm{M})$ for $5 \mathrm{~min}$ at $37^{\circ} \mathrm{C}$. Following treatment, cells were washed with ice-cold PBS twice, and lysed in ice-cold lysis buffer. The lysate was sonicated and centrifuged at $12,000 \mathrm{x} \mathrm{g}$ at $4^{\circ} \mathrm{C}$ for $5 \mathrm{~min}$. The protein concentration of extracts was determined by using the Bradford reagent from Bio-Rad Laboratories, Inc.. Equal amounts of protein (20 $\mu \mathrm{g} /$ lane) were loaded and separated by $12 \%$ SDS-PAGE. Proteins were transferred to nitrocellulose membranes (EMD Millipore, Billerica, MA, USA), and blocked in 5\% non-fat dry milk for $1 \mathrm{~h}$ at room temperature. Subsequently, the membrane was incubated with different primary antibodies including phosphor-ERK1/2 (Thr202/Tyr204), ERK1/2 and $\beta$-actin overnight at $4^{\circ} \mathrm{C}$ and then incubated with HRP-conjugated goat anti-rabbit IgG secondary antibody $(1: 20,000)$ for $2 \mathrm{~h}$ at room temperature. Immunoreactive bands were visualized by enhanced chemiluminescence (Pierce; Thermo Fisher Scientific, Inc.) and semi-quantified using ImageJ software (version 1.47t; National Institutes of Health, Bethesda, MD, USA).

MTT assay. Cellular viability was measured using the MTT assay as described previously (20). Briefly, cells were seeded in flat-bottomed 24 -well plates $\left(5 \times 10^{4}\right.$ cells/well) and grown for $24 \mathrm{~h}$ in DMEM supplemented with 10\% FBS. Following 
Table I. Primers used for reverse transcription PCR and quantitative PCR.

\begin{tabular}{lllr}
\hline Gene & Forward & \multicolumn{1}{c}{ Reverse } \\
\hline$\beta 1$-AR & 5'-GGGAGAAGCATTAGGAGGG-3' & 5'-CAAGGAAAGCAAGGTGGG-3' \\
$\beta 2$-AR & 5'-CAGCAAAGGGACGAGGTG-3' & 5'-AAGTAATGGCAAAGTAGCG-3' \\
$\beta$-actin & 5'-ATCGTGCGTGACATTAAGGAGAAG-3' & 5'-AGGAAGGAAGGCTGGAAGAGT-3' & 334 \\
MMP-2 & 5'-CCGTCGCCCATCATCAAGTTC-3' & 5'-GCAGCCATAGAAGGTGTTCAGG-3' & 179 \\
MMP-9 & 5'-TGGTCCTGGTGCTCCTGGTG-3' & 5'-GCTGCCTGTCGGTGAGATTGG-3' & 111 \\
\hline
\end{tabular}

PCR, polymerase chain reaction; $\beta$-AR, $\beta$-adrenergic receptors; MMP, matrix metalloproteinase.

$24 \mathrm{~h}$, cells were starved overnight at $37^{\circ} \mathrm{C}$ and incubated with different drugs. To determine the dose course effect of ISO on the proliferation of U251 and U87-MG cells, cells were treated with $0.1,1,5,10,30$ or $50 \mu \mathrm{M}$ ISO for $24 \mathrm{~h}$ at $37^{\circ} \mathrm{C}$. To determine the time course effect of ISO on the proliferation of U251 cells, cells were treated with ISO $(10 \mu \mathrm{M})$ for 24,48 , 72 and $96 \mathrm{~h}$ at $37^{\circ} \mathrm{C}$. To determine the effects of PRO and U0126 on ISO-mediated proliferation, cells were pretreated with PRO $(10 \mu \mathrm{M})$ or U0126 $(20 \mu \mathrm{M})$ for $30 \mathrm{~min}$ and then with ISO $(10 \mu \mathrm{M})$ for $48 \mathrm{~h}$ at $37^{\circ} \mathrm{C}$. Following drug treatment, $20 \mu \mathrm{l} \mathrm{MTT}(5 \mathrm{mg} / \mathrm{ml})$ was added to each well, and the cells were allowed to grow in complete media at $37^{\circ} \mathrm{C}$ for $3 \mathrm{~h}$. The supernatant was removed, then $500 \mu \mathrm{l}$ dimethyl sulfoxide was added to each well and mixed for $10 \mathrm{~min}$ to dissolve the crystal. Subsequently, the absorbance was determined using a microplate spectrophotometer assay reader at $570 \mathrm{~nm}$.

Statistical analysis. Data are indicated as the mean \pm standard error of the mean from at least three independent experiments. Statistical analysis was performed using the unpaired two-tailed Student's t-test (comparison of two groups) or one-way analysis of variance followed by the Tukey's test (comparison of $>2$ groups). $\mathrm{P}<0.05$ was considered to indicate a statistically significant difference. All statistical analyses were conducted using Prism version 6.0 (GraphPad Software, Inc., La Jolla, CA, USA).

\section{Results}

Expression of $\beta$-ARs in human glioblastoma cell lines. To detect whether $\beta$-ARs were expressed in cultured glioblastoma cells, the two cell lines U251 and U87-MG were profiled for $\beta_{1}$-AR and $\beta_{2}$-AR mRNA expression. The RT-qPCR analysis revealed that $\beta_{1}$-AR and $\beta_{2}$-AR transcripts were expressed in U251 cells; however, they were undetectable in U87-MG cells (Fig. 1A). These results were confirmed by RT-qPCR analysis (Fig. 1B). The $\beta_{2}$-AR transcript levels were increased compared with $\beta_{1}$-AR in U251 cells (Fig. $1 \mathrm{~B} ; \mathrm{P}=0.0135$ ). These data suggest that $\beta$-ARs may be functional and serve a role in the development process of U251 cells.

Isoproterenol promotes the proliferation of U251 cells. Based on the expression profile of $\beta$-ARs in U251, but not U87-MG cells, whether $\beta$-ARs activation was involved in U251 cell proliferation was then investigated. Firstly, the dose-dependent effect of ISO, an agonist of $\beta$-ARs, on the proliferation of U251
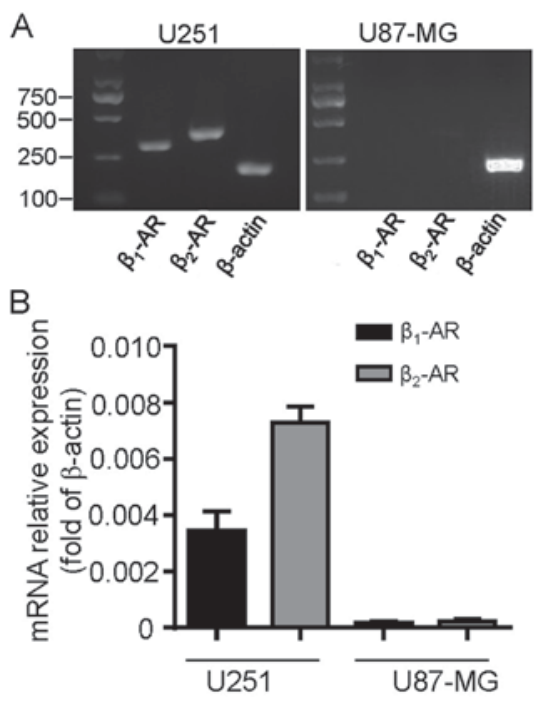

Figure 1. $\beta$-AR expression in human glioblastoma U251 and U87-MG cells. Expression of mRNA for $\beta_{1}$-AR, $\beta_{2}$-AR and $\beta$-actin by (A) reverse transcription PCR and (B) quantitative PCR in U251 and U87-MG cells. $\beta$-AR, $\beta$-adrenergic receptors; PCR, polymerase chain reaction.

cells was analyzed. The cells were treated with $0.1,1,5,10,30$ or $50 \mu \mathrm{M}$ ISO for $24 \mathrm{~h}$ and then proliferation was measured by MTT assay. These results revealed that ISO significantly increased the proliferation of $\mathrm{U} 251$ cells, which peaked at $10 \mu \mathrm{M}$ ISO and decreased at higher concentrations of ISO (Fig. 2A). Notably, no effect of ISO-mediated cell proliferation was detected in U87-MG cells (Fig. 2B). This is in accordance with the results demonstrating no expression of $\beta$-ARs in U87-MG cells (Fig. 1A). Secondly, the effect of different time treatment of ISO on U251 cell proliferation was detected. The cells were incubated with $10 \mu \mathrm{M}$ ISO for $24,48,72$ or $96 \mathrm{~h}$. As indicated in Fig. 2C, ISO significantly increased the proliferation of U251 cells, with the most marked effect at $48 \mathrm{~h}$. Thus, $10 \mu \mathrm{M}$ ISO was chosen as the reference concentration, and $48 \mathrm{~h}$ as the treatment time for the following studies unless specifically indicated.

To additionally confirm that ISO-induced proliferation was specifically mediated by $\beta$-ARs, the U251 cells were pretreated with $\beta$-AR antagonist PRO and then stimulated by ISO. As expected, PRO pre-treatment to block endogenous $\beta$-ARs activity significantly suppressed ISO-induced U251 cell proliferation (Fig. 2D). Taken together, these results indicate that specific activation of $\beta$-ARs is able to promote the cell proliferation in U251 cells. 
A

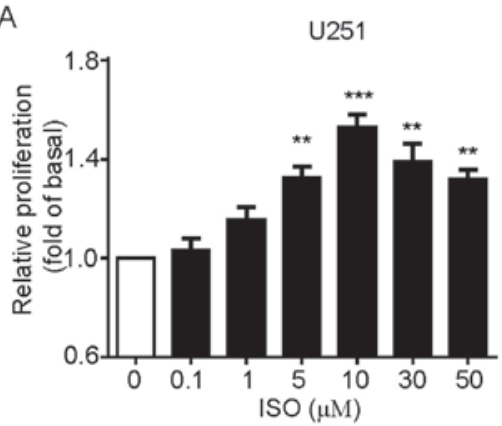

C

$\square$ Control

- ISO $(10 \mu \mathrm{M})$

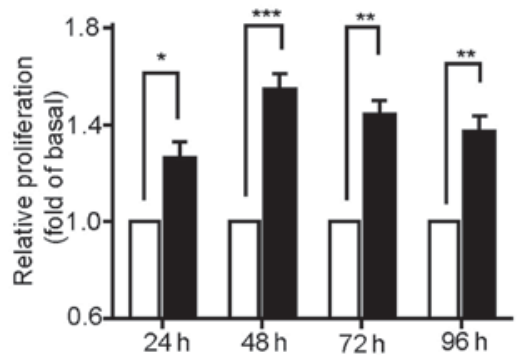

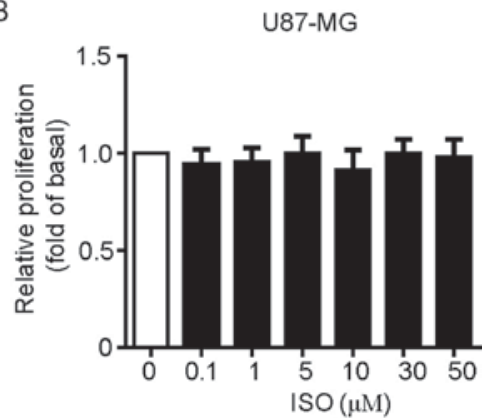

D

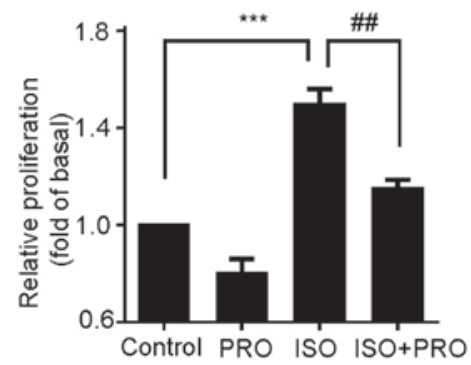

Figure 2. $\beta$-AR activation promotes U251 cell proliferation. (A) Effects of ISO on the cell proliferation of U251 cells. Cells were treated with various concentrations of ISO as indicated for $48 \mathrm{~h}$, and cell proliferation was assessed by MTT assay. ${ }^{* * *} \mathrm{P}<0.01,{ }^{* * * *} \mathrm{P}<0.001 \mathrm{vs}$. control group. (B) Effects of ISO on the cell proliferation of U87-MG cells. (C) Time-course stimulation of U251 cells with $10 \mu \mathrm{M}$ ISO for $24,48,72$ and $96 \mathrm{~h} .{ }^{*} \mathrm{P}<0.05,{ }^{* * *} \mathrm{P}<0.01,{ }^{* * *} \mathrm{P}<0.001$ vs. control groups. (D) Effects of the $\beta$-AR antagonist PRO on ISO-induced cell proliferation. Cells were incubated with PRO for 30 min prior to and during treatment with ISO for $48 \mathrm{~h}$. Values represent the mean \pm standard error of the mean from at least three triplicate experiments. ${ }^{* * *} \mathrm{P}<0.001 \mathrm{vs}$. control group, ${ }^{\# \#} \mathrm{P}<0.01 \mathrm{vs}$. ISO-treated group. $\beta$-AR, $\beta$-adrenergic receptors; ISO, isoproterenol; PRO, propranolol.

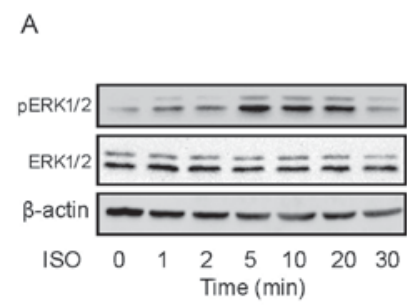

C

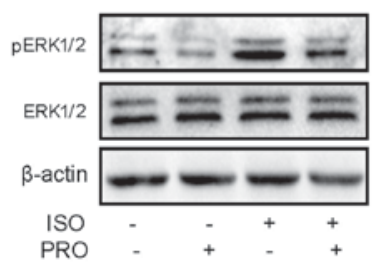

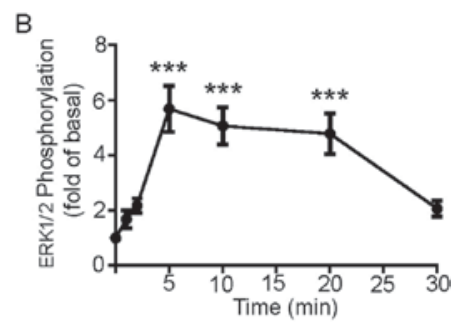

D

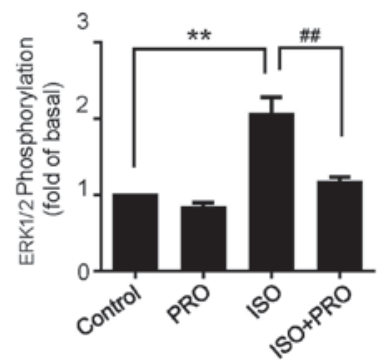

Figure 3. Activation of $\beta$-adrenergic receptors increases the ERK1/2 phosphorylation in U251 cells. (A) Effects of $10 \mu \mathrm{M}$ ISO in the increase of transient ERK1/2 phosphorylation. Blots are representative of three independent experiments. (B) Quantitation of western blotting results from A. (C) Effects of PRO on ISO-induced ERK1/2 phosphorylation. (D) Quantitation of western blotting results from C. Values represent the mean \pm standard error of the mean from at least three triplicate experiments. ${ }^{* *} \mathrm{P}<0.01 \mathrm{vs}$. control group, ${ }^{\# \#} \mathrm{P}<0.01$ vs. ISO-treated group. ISO, isoproterenol; $\mathrm{PRO}$, propranolol; ERK, extracellular signal-related kinase; p, phosphorylated.

$\beta$-ARs activation induces ERK $K_{1 / 2}$ phosphorylation in U251 cells. The aforementioned results indicated that ISO treatment may significantly promote U251 cell proliferation. The underlying molecular mechanisms of ISO-induced cell

proliferation in U251 cells were then explored. MAPK pathways have been widely recognized to regulate a variety of physiological processes including cell proliferation, differentiation and apoptosis in cancer cells (21). Thus, to define the role of MAPK cascades in the effect elicited by ISO, cells were treated with $10 \mu \mathrm{M}$ ISO for 1, 2, 5, 10, 20 and $30 \mathrm{~min}$, and then ERK1/2 phosphorylation levels were detected using western blotting. ISO induced ERK1/2 phosphorylation in a rapid and transient manner, which peaked at $5 \mathrm{~min}$ and decreased following $20 \mathrm{~min}$, while ERK1/2 expression levels remained unchanged (Fig. 3A and B). Additionally, ERK1/2 phosphorylation was significantly blocked by PRO pretreatment (Fig. $3 \mathrm{C}$ and $\mathrm{D}$ ), suggesting $\beta$-ARs activation is able to induce ERK1/2 phosphorylation in U251 cells.

ISO-induced proliferation is mediated by ERK $K_{1 / 2}$ pathway. Whether ISO-mediated ERK1/2 activation was involved in cell proliferation of U251 cells was investigated. The effects of U0126, a specific MAPK/ERK (MEK)1/2 inhibitor, on ISO-induced ERK1/2 phosphorylation were first explored. As demonstrated in Fig. 4A and B, pretreating U251 cells with U0126 effectively abolished ISO-induced ERK1/2 phosphorylation. Next, the MTT assay showed that the proliferative effects of ISO were also significantly suppressed by U0126 (Fig. 4C). These results indicate that ERK1/2 pathway is essential for ISO-mediated proliferation in U251 cells. expression through ERK1/2 activation. MMPs, particularly 
A

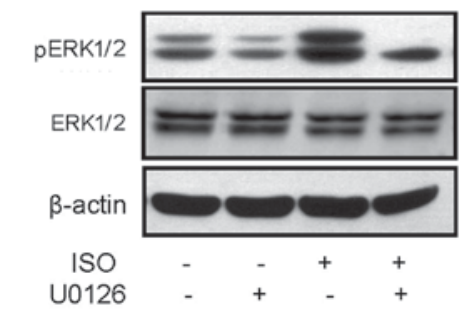

B

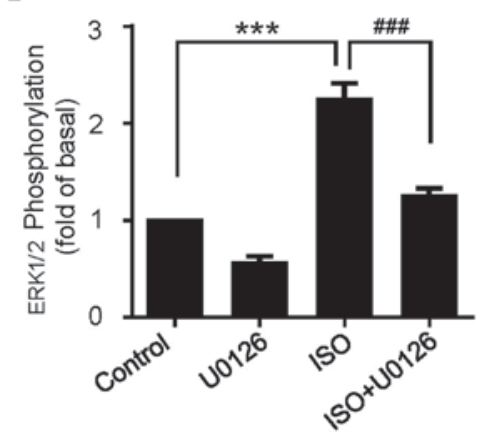

C

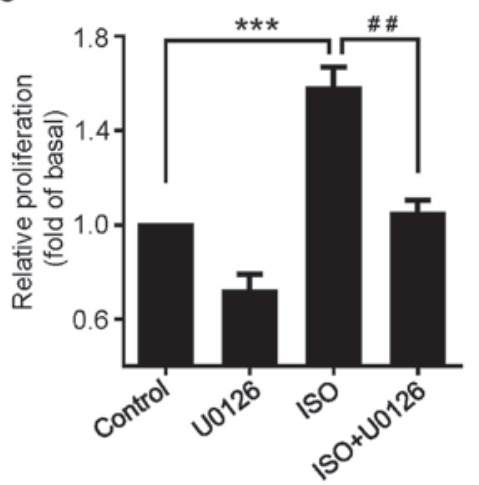

Figure 4. $\beta$-adrenergic receptor-dependent cell proliferation is mediated by ERK1/2 phosphorylation. (A) Effects of U0126 on ISO-induced ERK1/2 phosphorylation. Blots are representative of three separate experiments. (B) Quantitation of western blotting results in A, values represent the mean \pm SEM from three separate sets of immunoblots. ${ }^{* *} \mathrm{P}<0.01$ vs. control group, ${ }^{\# \#} \mathrm{P}<0.01$ vs. ISO-treated group. (C) Effects of U0126 on ISO-induced cell proliferation. Values represent the mean \pm SEM from at least three triplicate experiments. ${ }^{* *} \mathrm{P}<0.01$ vs. control group, ${ }^{\# \#} \mathrm{P}<0.01$ vs. ISO-treated group. ISO, isoproterenol; PRO, propranolol; ERK, extracellular signal-related kinase; p, phosphorylated; SEM, standard error of the mean.

the gelatinases MMP-2 and MMP-9, have been documented as key factors to the proliferation and invasion of cancer cells $(22,23)$. Whether $\beta$-ARs activation regulates the expression of $M M P-2$ and MMP-9 mRNA in U251 cells was then examined. As demonstrated in Fig. 5A, the results indicated that $M M P-2$ and $M M P-9$ mRNA expression was significantly upregulated following ISO treatment. In addition, the pretreatment of U251 cells with U0126 inhibited ISO-induced MMP-2 and MMP-9 mRNA expression (Fig. 5B and C). These results suggest that $\beta$-ARs-mediated $M M P-2$ and $M M P-9$ mRNA expression occurs through the ERK1/2 pathway.

\section{Discussion}

The main results of the present study concern the mechanism of $\beta$-ARs-mediated cell proliferation of glioblastoma cells. It
A

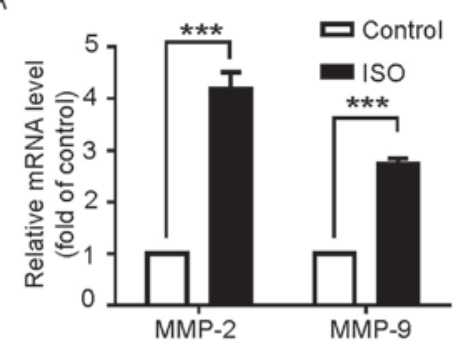

B

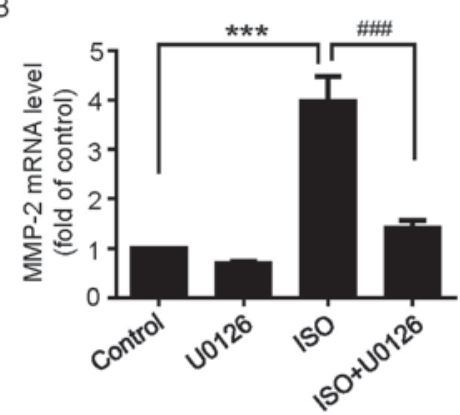

C

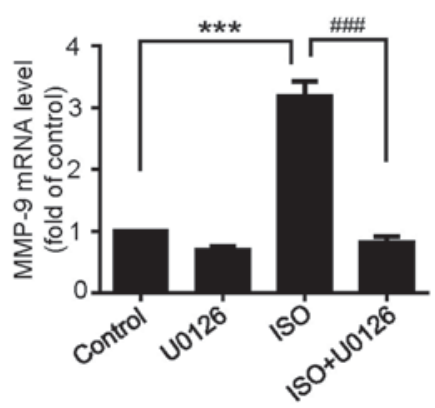

Figure 5. $\beta$-adrenergic receptors induce $M M P-2$ and $M M P-9$ mRNA expression, mediated by the extracellular signal-related kinase $1 / 2$ pathway. (A) Effects of ISO on the expression of $M M P-2$ and $M M P-9$ mRNA. Cells were stimulated with $10 \mu \mathrm{M}$ ISO for $48 \mathrm{~h}$, then a quantitative reverse transcription polymerase chain reaction was performed to detect the mRNA level of $M M P-2$ and $M M P-9$. ${ }^{* * * *} \mathrm{P}<0.001$ vs. control groups. Effects of $\mathrm{U} 0126$ on ISO-induced (B) $M M P-2$ and (C) $M M P-9$ mRNA expression. ${ }^{* * *} \mathrm{P}<0.001$ vs. control groups, ${ }^{\# \#} \mathrm{P}<0.001$ vs. ISO-treated groups. Values represent the mean \pm standard error of the mean from at least three triplicate experiments. ISO, isoproterenol; PRO, propranolol; MMP, matrix metalloproteinase.

was demonstrated that: i) $\beta_{1}-\mathrm{AR}$ and $\beta_{2}-\mathrm{AR}$ are expressed in $\mathrm{U} 251$ cells but not in U87-MG cells; ii) activation of $\beta$-ARs by ISO promoted the proliferation of U251 cells through the ERK1/2 pathway; and iii) $\beta$-ARs activation increased MMP-2 and MMP-9 mRNA expression, which may be important for U251 cell proliferation.

Previous studies have demonstrated that $\beta$-ARs are expressed in human clinical glioblastoma specimens obtained from operated patients $(24,25)$. Additionally, studies have indicated that $\beta$-ARs are also expressed in glioblastoma cell lines and primary cultures derived from human biopsies (26) and in the human-derived $1321 \mathrm{~N} 1$ astrocytoma cell line (27). In addition, studies with the human-derived U118 glioma cell line indicate that there is a low but significant expression of $\beta$-ARs in these cells, but to a lesser extent compared with $1321 \mathrm{~N} 1$ cells (18). However, the function of $\beta$-ARs in U87-MG cells remains debated. Previous studies demonstrate that in vitro U87-MG cells do not express functional 
$\beta$-ARs $(18,24)$. However, all three subtypes of $\beta$-ARs appear to be detectable in U87-MG tumors in vivo, indicating that $\beta$-ARs expression processes may take place and may be functional during tumor development (24). Additionally, (R, R')-4-methoxy-1-naphthylfenoterol, a selective $\beta_{2}$-AR agonist, was identified to inhibit cellular proliferation of U87-MG cells (28). All these data suggest that $\beta$-ARs may also be functional, by an unknown mechanism. Nevertheless, the exact function of $\beta$-ARs in U251 glioma cells and the underlying mechanism are not fully understood. In the present study, the expression of $\beta$-ARs in U251 and U87-MG cells was first measured by RT-PCR and RT-qPCR. The results demonstrated that $\beta_{1}$-ARs and $\beta_{2}$-ARs were expressed in U251 cells, but not in U87-MG cells, which was consistent with a previous study (24).

In previous years, evidence has suggested that $\beta$-AR agonists and antagonists affect cell growth and function, which may lead to the inhibition or induction of malignant diseases (29). The effect of $\beta$-AR activation is cell-specific as $\beta_{2}$-AR antagonists and agonists have been demonstrated to attenuate cell growth. For example, $\beta$-ARs activation may promote cell proliferation of certain cancer cells including lung cancer cells (20), ovarian carcinoma (5), human hepatocellular carcinoma cells (30), pancreatic (31), prostate (32), gastric (33) and colorectal cancer cells (34). By contrast, several studies have demonstrated that the $\beta$-AR agonist ISO suppresses the proliferation of MDA-MB-231 human breast cancer cells $(35,36)$. In addition, in U118 glioma cells and $132 \mathrm{~N} 1$ astrocytoma cells, treatment with $\beta_{2}$-AR agonists $\left(\mathrm{R}, \mathrm{R}^{\prime}\right)$-fenoterol or isoproterenol inhibited cell proliferation (18). However, the results of the present study indicated that the activation of $\beta$-ARs by ISO promoted U251 cell proliferation. How this difference occurs, and the underlying mechanism, requires additional investigation. As aforementioned, obtaining $\beta$-AR expression in U87-MG tumors in vivo would imply that $\beta$-AR may facilitate tumor formation by promoting cellular proliferation. Another potential probability is that this cell type-specific divergence on cellular proliferation may be due to cross-talk between $\beta$-ARs and other GPCR-linked signaling cascades including gamma-aminobutyric acid $B$ receptors $\left(\mathrm{GABA}_{B} \mathrm{R}\right)$ (37), $\alpha_{2}$-AR (38), bradykinin $B_{2}$ receptor (39), oxytocin (40), and cannabinoid receptors (28). For example, the ISO-induced signaling cascade, cellular proliferation and cellular migration in pancreatic ductal adenocarcinoma cells may be potently inhibited following stimulation of $\mathrm{GABA}_{\mathrm{B}} \mathrm{R}$ signaling (37).

The MMPs are a family of proteolytic enzymes that regulate various cell behaviors that are relevant in cancer biology through the degradation of the extracellular matrix surrounding tumors (41). Although MMPs, particularly MMP-2 and MMP-9, have been considered to be important factors in facilitating invasion and metastases through the degradation of type IV collagen, a major component of the basement membrane, additional evidence also demonstrates that MMPs may promote cancer cell proliferation (23). Previous, studies have suggested that NE may affect the progression of ovarian cancer by modulating the expression of MMPs and the angiogenic cytokine, vascular endothelial growth factor, in ovarian cancer cells (42). Additionally, $\beta$-ARs inhibition suppressed the expression of MMP-2 and MMP-9 in human brain microvascular endothelial cells (24) thus increasing the proliferative, invasive and metastatic potential of these cells. In the present study, it was revealed that MMP-2 and MMP-9 mRNA expression was significantly increased upon $\beta$-ARs activation. Consistently, the proliferation of U251 cells was also enhanced through the activation of $\beta$-ARs. In addition, pretreatment with U0126 to block ERK1/2 activity significantly reduced the upregulation of MMP-2 and MMP-9. Previous studies have demonstrated that the activation of the EGFR-MEK-ERK signaling pathway causes the overexpression of MMP-2 and MMP-9 in prostate cancer cells (43). However, whether EGFR transactivation pathway or/and other signaling cascades are involved in $\beta$-ARs-induced cell proliferation in glioblastoma cells requires additional study.

\section{Acknowledgements}

The present study was supported by the Natural Science Foundation of China (grant no. 81601179), Natural Science Foundation of Jiangxi Province of China (grant nos. 20171BAB215039, 20122BAB215020, 20161BAB204166 20161BAB205212 and 20171BAB214022).

\section{References}

1. Dolecek TA, Propp JM, Stroup NE and Kruchko C: CBTRUS statistical report: Primary brain and central nervous system tumors diagnosed in the United States in 2005-2009. Neuro Oncol 14 (Suppl 5): v1-v49, 2012.

2. Wen PY and Kesari S: Malignant gliomas in adults. N Engl J Med 359: 492-507, 2008.

3. Stupp R and Roila F; ESMO Guidelines Working Group: Malignant glioma: ESMO clinical recommendations for diagnosis, treatment and follow-up. Ann Oncol 20 (Suppl 4): S126-S128, 2009.

4. Nagaraja AS, Armaiz-Pena GN, Lutgendorf SK and Sood AK: Why stress is BAD for cancer patients. J Clin Invest 123: 558-560, 2013.

5. Thaker PH,Han LY, Kamat AA, Arevalo JM, Takahashi R, Lu C, Jennings NB, Armaiz-Pena G, Bankson JA, Ravoori M, et al: Chronic stress promotes tumor growth and angiogenesis in a mouse model of ovarian carcinoma. Nat Med 12: 939-944, 2006.

6. Hassan S, Karpova Y, Baiz D, Yancey D, Pullikuth A, Flores A, Register T, Cline JM, D'Agostino R Jr, Danial N, et al: Behavioral stress accelerates prostate cancer development in mice. J Clin Invest 123: 874-886, 2013

7. Timmermans W, Xiong H, Hoogenraad $\mathrm{CC}$ and Krugers $\mathrm{HJ}$ : Stress and excitatory synapses: From health to disease. Neuroscience 248: 626-636, 2013.

8. de Kloet ER, Joëls M and Holsboer F: Stress and the brain: From adaptation to disease. Nat Rev Neurosci 6: 463-475, 2005.

9. Fitzgerald PJ: Is norepinephrine an etiological factor in some types of cancer? Int J Cancer 124: 257-263, 2009.

10. Woo AY and Xiao RP: $\beta$-adrenergic receptor subtype signaling in heart: From bench to bedside. Acta Pharmacol Sin 33: 335-341, 2012.

11. Schuller HM and Al-Wadei HA: Neurotransmitter receptors as central regulators of pancreatic cancer. Future Oncol 6: 221-228, 2010.

12. Cohen S, Janicki-Deverts D and Miller GE: Psychological stress and disease. JAMA 298: 1685-1687, 2007.

13. Schuller HM: Beta-adrenergic signaling, a novel target for cancer therapy? Oncotarget 1: 466-469,2010.

14. Braadland PR, Ramberg H, Grytli HH and Taskén KA: $\beta$-adrenergic receptor signaling in prostate cancer. Front Oncol 4: 375,2015

15. Al-Wadei HA, Al-Wadei MH and Schuller HM: Prevention of pancreatic cancer by the beta-blocker propranolol. Anticancer Drugs 20: 477-482, 2009. 
16. Askari MD, Tsao MS and Schuller HM: The tobacco-specific carcinogen, 4-(methylnitrosamino)-1-(3-pyridyl)-1-butanone stimulates proliferation of immortalized human pancreatic duct epithelia through beta-adrenergic transactivation of EGF receptors. J Cancer Res Clin Oncol 131: 639-648, 2005.

17. Weddle DL, Tithoff P, Williams $M$ and Schuller HM: Beta-adrenergic growth regulation of human cancer cell lines derived from pancreatic ductal carcinomas. Carcinogenesis 22 : 473-479, 2001

18. Toll L, Jimenez L, Waleh N, Jozwiak K, Woo AY, Xiao RP, Bernier $M$ and Wainer IW: \{Beta\}2-adrenergic receptor agonists inhibit the proliferation of $1321 \mathrm{~N} 1$ astrocytoma cells J Pharmacol Exp Ther 336: 524-532, 2011.

19. Livak KJ and Schmittgen TD: Analysis of relative gene expression data using real-time quantitative PCR and the 2(-Delta Delta C(T)) method. Methods 25: 402-408, 2001.

20. Hu P, He J, Liu S, Wang M, Pan B and Zhang W: $\beta 2$-adrenergic receptor activation promotes the proliferation of A549 lung cancer cells via the ERK1/2/CREB pathway. Oncol Rep 36 : $1757-1763,2016$

21. Dhillon AS, Hagan S, Rath O and Kolch W: MAP kinase signalling pathways in cancer. Oncogene 26: 3279-3290, 2007.

22. Dong W, Li H, Zhang Y, Yang H, Guo M, Li L and Liu T: Matrix metalloproteinase 2 promotes cell growth and invasion in colorectal cancer. Acta Biochim Biophys Sin (Shanghai) 43: 840-848, 2011.

23. Egeblad M and Werb Z: New functions for the matrix metalloproteinases in cancer progression. Nat Rev Cancer 2: 161-174, 2002.

24. Annabi B, Lachambre MP, Plouffe K, Moumdjian R and Béliveau R: Propranolol adrenergic blockade inhibits human brain endothelial cells tubulogenesis and matrix metalloproteinase-9 secretion. Pharmacol Res 60: 438-445, 2009.

25. Sardi I, Giunti L, Bresci C, Buccoliero AM, Degl'innocenti D, Cardellicchio S, Baroni G, Castiglione F, Ros MD, Fiorini P, et al: Expression of $\beta$-adrenergic receptors in pediatric malignant brain tumors. Oncol Lett 5: 221-225, 2013.

26. Prenner L, Sieben A, Zeller K, Weiser D and Häberlein $H$ Reduction of high-affinity beta2-adrenergic receptor binding by hyperforin and hyperoside on rat C6 glioblastoma cells measured by fluorescence correlation spectroscopy. Biochemistry 46 : 5106-5113, 2007.

27. Wakshull E, Hertel C, O'Keefe EJ and Perkins JP: Cellular redistribution of beta-adrenergic receptors in a human astrocytoma cell line: A comparison with the epidermal growth factor receptor in murine fibroblasts. J Cell Biochem 29: 127-141, 1985.

28. Paul RK, Ramamoorthy A, Scheers J, Wersto RP, Toll L, Jimenez L, Bernier M and Wainer IW: Cannabinoid receptor activation correlates with the proapoptotic action of the 32-adrenergic agonist (R, R')-4-methoxy-1-naphthylfenoterol in HepG2 hepatocarcinoma cells. J Pharmacol Exp Ther 343: $157-166,2012$
29. Evans BA, Sato M, Sarwar M, Hutchinson DS and Summers RJ: Ligand-directed signalling at beta-adrenoceptors. Br J Pharmacol 159: 1022-1038, 2010.

30. Yuan A, Li Z, Li X, Yi S, Wang S, Cai Y and Cao H: The mitogenic effectors of isoproterenol in human hepatocellular carcinoma cells. Oncol Rep 23: 151-157, 2010.

31. Pham H, Chen M, Takahashi H, King J, Reber HA, Hines OJ, Pandol S and Eibl G: Apigenin inhibits NNK-induced focal adhesion kinase activation in pancreatic cancer cells. Pancreas 41: 1306-1315, 2012

32. Zhang P, He X, Tan J, Zhou X and Zou L: $\beta$-arrestin 2 mediates $\beta-2$ adrenergic receptor signaling inducing prostate cancer cell progression. Oncol Rep 26: 1471-1477, 2011.

33. Shin VY, Wu WK, Chu KM, Koo MW, Wong HP, Lam EK, Tai EK and Cho CH: Functional role of beta-adrenergic receptors in the mitogenic action of nicotine on gastric cancer cells. Toxicol Sci 96: 21-29, 2007.

34. Coelho M, Moz M, Correia G, Teixeira A, Medeiros R and Ribeiro L: Antiproliferative effects of $\beta$-blockers on human colorectal cancer cells. Oncol Rep 33: 2513-2520, 2015

35. Slotkin TA, Zhang J, Dancel R, Garcia SJ, Willis C and Seidler FJ: Beta-adrenoceptor signaling and its control of cell replication in MDA-MB-231 human breast cancer cells. Breast Cancer Res Treat 60: 153-166, 2000

36. Carie AE and Sebti SM: A chemical biology approach identifies a beta-2 adrenergic receptor agonist that causes human tumor regression by blocking the Raf-1/Mek-1/Erk1/2 pathway. Oncogene 26: 3777-3788, 2007.

37. Schuller HM, Al-Wadei HA and Majidi M: GABA B receptor is a novel drug target for pancreatic cancer. Cancer 112: 767-778, 2008.

38. Cottingham $\mathrm{C}, \mathrm{Lu} \mathrm{R}$, Jiao $\mathrm{K}$ and Wang Q: Cross-talk from $\beta$-adrenergic receptors modulates $\alpha 2 \mathrm{~A}$-adrenergic receptor endocytosis in sympathetic neurons via protein kinase A and spinophilin. J Biol Chem 288: 29193-29205, 2013.

39. Hanke S, Nürnberg B, Groll DH and Liebmann C: Cross talk between beta-adrenergic and bradykinin $\mathrm{B}(2)$ receptors results in cooperative regulation of cyclic AMP accumulation and mitogen-activated protein kinase activity. Mol Cell Biol 21: 8452-8460, 2001

40. Wrzal PK, Goupil E, Laporte SA, Hébert TE and Zingg HH: Functional interactions between the oxytocin receptor and the $\beta 2$-adrenergic receptor: Implications for ERK1/2 activation in human myometrial cells. Cell Signal 24: 333-341, 2012.

41. Deryugina EI and Quigley JP: Matrix metalloproteinases and tumor metastasis. Cancer Metastasis Rev 25: 9-34, 2006.

42. Moreno-Smith M, Lutgendorf SK and Sood AK: Impact of stress on cancer metastasis. Future Oncol 6: 1863-1881, 2010.

43. Xiao LJ, Lin P, Lin F, Liu X, Qin W, Zou HF, Guo L, Liu W, Wang SJ and Yu XG: ADAM17 targets MMP-2 and MMP-9 via EGFR-MEK-ERK pathway activation to promote prostate cancer cell invasion. Int J Oncol 40: 1714-1724, 2012. 